\title{
The effects of Tenidap on cytokine induced proliferation of human synovial fibroblasts in vitro
}

\author{
D L Mattey, E Evans, P T Dawes
}

\begin{abstract}
Objectives-Tenidap, a new antirheumatic agent, is a lipoxygenase and cyclooxygenase inhibitor, and is reported to inhibit the production and action of interleukin 1 (IL-1). Since eicosanoids, IL-1, and other cytokines may influence the growth of fibroblasts in the joint synovium the study was carried out to determine the effects of Tenidap on cytokine induced proliferation of these cells in vitro.

Methods-Cell cultures derived from patients with a variety of rheumatic diseases were cultured in different concentrations of Tenidap sodium, with or without IL-1, tumour necrosis factor alpha (TNF), IL-6, basic fibroblast growth factor (bFGF), or transforming growth factor beta (TGFB). Cell proliferation was measured using a crystal violet colourimetric assay. Prostaglandin $\mathrm{E}_{2}$ levels in culture supernatants were measured by radioimmunoassay.
\end{abstract}

Results-Tenidap at concentrations above $10 \mu \mathrm{g} / \mathrm{ml}$ inhibited cell growth, while at $1.25-5 \mu \mathrm{g} / \mathrm{ml}$ there was a small but significant increase in proliferation compared with controls. A further increase in growth was obtained when cells were incubated with Tenidap + IL-1, TNF or bFGF, and this was significantly higher than in the presence of any cytokine alone. Stimulation of IL-1 induced growth by Tenidap was reduced by addition of high levels of exogenous PGE $_{2}$ (100 $\mathrm{ng} / \mathrm{ml}$ ) although growth was still higher than in IL-1 alone.

Conclusions-Depending on concentration, Tenidap may inhibit or stimulate synovial fibroblast growth. Our results suggest that augmentation of growth by low concentrations cannot be explained by inhibition of $\mathrm{PGE}_{2}$ production alone. Tenidap may directly stimulate cell growth or may block other fibroblast factors which are involved in control of cytokine induced proliferation.

(Ann Rheum Dis 1994; 53: 250-255)

Proliferation of synovial fibroblasts is a recognised feature of rheumatoid arthritis (RA) although it is still unclear which factors are responsible for driving this phenomenon. Many growth factors/cytokines have been implicated, including platelet derived growth factor (PDGF), ${ }^{1}$ epidermal growth factor
$(\mathrm{EGF}){ }^{2}$ acidic and basic fibroblast growth factors (FGFs), ${ }^{3}$ tumour necrosis factor alpha (TNF), ${ }^{5}$ as well as combinations of cytokines (for example, interleukin-1 and transforming growth factor $\beta) .{ }^{6}$ The major source of these factors is believed to be leukocyte populations, particularly mononuclear phagocytes, which infiltrate the rheumatoid joint during inflammation.

Synovial fibroblasts are likely to play an important role in the inflammatory process since they have been shown to produce various mediators, including cytokines, ${ }^{7}$ prostaglandins ${ }^{8}$ and proteolytic enzymes such as collagenase and stromelysin. ${ }^{8} 9$ They may also orchestrate the responses of other cells within the synovium and may affect the survival of lymphocytes and other haemopoietic cells within the joint. ${ }^{10}$

The proliferation of synovial fibroblasts may be affected not only by factors produced within the joint but also by various anti-inflammatory drugs and second-line agents administered to patients with RA. Since most patients with RA are on such agents it is difficult to assess the role of individual growth promoting (or inhibiting) factors produced in vivo. For example, non-steroidal anti-inflammatory drugs (NSAIDS) inhibit production of prostanoids such as prostaglandin $\mathrm{E}_{2}\left(\mathrm{PGE}_{2}\right)$ which is generally inhibitory to fibroblast cell growth. It has been shown that treatment with the NSAID indomethacin increases synovial fibroblast cell growth in vitro in the presence of interleukin-1 $\beta$ or TNF. ${ }^{11}$ Furthermore IL-1 and PDGF act synergistically to stimulate synovial fibroblast proliferation in the presence of indomethacin. ${ }^{1}$ Other cyclo-oxygenase inhibitors and glucocorticoids have similar enhancing effects on IL-1 $\beta$ induced fibroblast proliferation. ${ }^{11}$ In contrast, the second line agent D-penicillamine causes suppression of human skin fibroblasts in the presence of physiological levels of copper sulphate. ${ }^{12}$ This inhibition was attributed to the production of hydrogen peroxide in the presence of these agents. Thus drugs which affect the production of growth inhibitory (or growth promoting) factors may have long term effects on proliferation and/or survival of synovial fibroblasts, and may have significant effects on cellular interactions within the joint. The clinical consequences of such effects are poorly understood at present.

Tenidap sodium, a novel anti-inflammatory drug which has combined inhibitory activity against the cyclooxygenase and 5-lipoxygenase pathways, ${ }^{13} 14$ is reported to inhibit the production of IL-1, IL-6 and TNF ${ }^{15} 16$ and the 
action of IL- $1 .{ }^{17}$ It also inhibits the release of activated neutrophil collagenase. ${ }^{18}$ Since inhibition of eicosanoids and cytokines may have significant effects on synovial fibroblast growth, we have investigated the effects of Tenidap, alone or combined with various cytokines, on proliferation of these cells in vitro.

\section{Materials and methods \\ 1) CELLS \\ Human synovial tissue was obtained, with Ethical Committee approval, from patients undergoing surgery. Synovial fibroblasts were released from the tissue by digestion of syno- vium with $2 \mathrm{mg} / \mathrm{ml}$ collagenase (Type 1A, Sigma). Skin fibroblasts were obtained from slices of epidermis/dermis from healthy volun- teers. We established three normal skin fibro- blast cell cultures and 17 synovial fibroblast cell cultures from patients with a variety of rheumatic conditions. Cells were maintained in Dulbecco's Modified Eagles Medium (DMEM) with $10 \%$ foetal calf serum (FCS), glutamine, penicillin and streptomycin (com- plete culture medium, CCM). Experiments were carried out on cells at various passage numbers (2-30). Most experiments were performed on cells between passage 2 and 10 .}

\section{2) PROLIFERATION ASSAY}

We used a crystal violet colourimetric technique to examine the growth of fibroblasts in 96 well plates. ${ }^{19}$ Cells were seeded at a density of $5 \times 10^{3}$ cells/well in CCM. Cells were cultured for three days in CCM, followed by 48 hours of serum starvation in DMEM with $0.2 \%$ foetal calf serum to take cells into quiescence (Go). After serum starvation, experiments were carried out either in CCM or serum free medium (SFM) consisting of DMEM with insulin $(25 \mu \mathrm{g} / \mathrm{ml})$, transferrin $(25 \mu \mathrm{g} / \mathrm{ml})$ and sodium selenite $(25 \mathrm{ng} / \mathrm{ml})$ (Sigma), plus $0.1 \%$ bovine serum albumin (BSA). Test medium (for example, SFM + Tenidap) was added to the cells which were then incubated for a further seven days. In preliminary experiments cells were examined for growth at various time points. We found that cells continued to proliferate over a seven day period and that although increases in growth were measurable within two to three days they were far more marked after seven days, as were differences between treatments. After culture the medium was removed and the cells were fixed for one hour at room temperature with $3.5 \%$ formaldehyde in phosphate buffered saline (PBS). One plate was always fixed after serum starvation and before addition of test medium to give the baseline value (day 0 ). Internal standardisation of each assay was carried out by seeding an additional plate with single, double and multiple amounts of starting cell numbers. Plates were washed three times by submersion in deionised water.

After air-drying (approx two hours) the cells were stained by addition of $100 \mu \mathrm{l}$ of a $0 \cdot 1 \%$ solution of crystal violet dissolved in $200 \mathrm{mM}$
Mes, $\mathrm{pH} 6 \cdot 0$. The plates were shaken at room temperature for 20 minutes and excess dye was removed by extensive washing with deionised water. Plates were air-dried before solubilisation of the bound dye in $100 \mu \mathrm{l}$ of $10 \%$ acetic acid. The optical density (OD) of the dye extracts was measured directly in the plates using a Titertek Multiskan Plus Mk II microplate reader at a wavelength of $590 \mathrm{~nm}$. Quadruplicate determinations were made at each experimental point. Blank values were obtained from quadruplicates of cell free wells on each plate which were stained in an identical way to those containing cells. Experiments with different cell cultures showed a direct correlation between OD and cell numbers (not shown). The effects of Tenidap $+/-$ cytokines on cell growth were represented by plotting cell numbers (calculated from OD values) against drug concentration.

The percentage growth relative to untreated controls was calculated as follows:-

$\%$ growth $=$

$$
\frac{\mathrm{OD}(\text { test/day } 7)-\mathrm{OD}(\text { day } 0)}{\mathrm{OD}(\text { control/day } 7 \text { ) - OD (day } 0)} \times 100
$$

Day $0=$ cells after 48 hours serum starvation Day $7=$ cells after 48 hours serum starvation +7 days test or control medium

Tenidap sodium was dissolved in DMSO, at a concentration of $10 \mathrm{mg} / \mathrm{ml}$ before dilution in culture medium. Indomethacin was prepared in a similar way. The following cytokines were used alone or in combination with Tenidap: IL-1 alpha (human recombinant, 0.1-10 ng/ $\mathrm{ml}$ ), TNF alpha (human recombinant, $0 \cdot 1-10$ $\mathrm{ng} / \mathrm{ml}$ ), IL-6 (human recombinant, $0.5-5 \mathrm{ng} /$ $\mathrm{ml}$ ), basic FGF (human recombinant, $0 \cdot 1-10$ $\mathrm{ng} / \mathrm{ml}$ ), TGF beta (from human platelets, $0 \cdot 1-5 \cdot 0 \mathrm{ng} / \mathrm{ml}$ ). TGF beta was obtained from Sigma. All other cytokines were from British Biotechnology Ltd.

3) $\mathrm{PGE}_{2}$ MEASUREMENT

$\mathrm{PGE}_{2}$ was measured by a standard radioimmunoassay (Amersham) on cell free supernatants from the 96 well growth assay plates. Supernatants were stored at $-70^{\circ} \mathrm{C}$ before use.

\section{STATISTICAL METHODS}

The Wilcoxon test for matched pairs (non parametric data) or the paired $t$ test (parametric data) was employed to determine the significance of the difference in cell growth between fibroblast cultures treated with or without Tenidap. All statistics were calculated using the Number Cruncher Statistical System.

\section{Results}

CELL PROLIFERATION

\section{(1) Tenidap}

A range of concentrations of Tenidap sodium $(0 \cdot 1-80 \mu \mathrm{g} / \mathrm{ml})$ were tested in our proliferation assays. In most cell cultures, Tenidap above 10 $\mu \mathrm{g} / \mathrm{ml}$ in SFM inhibited cell proliferation. At higher concentrations $(>20 \mu \mathrm{g} / \mathrm{ml})$ Tenidap 


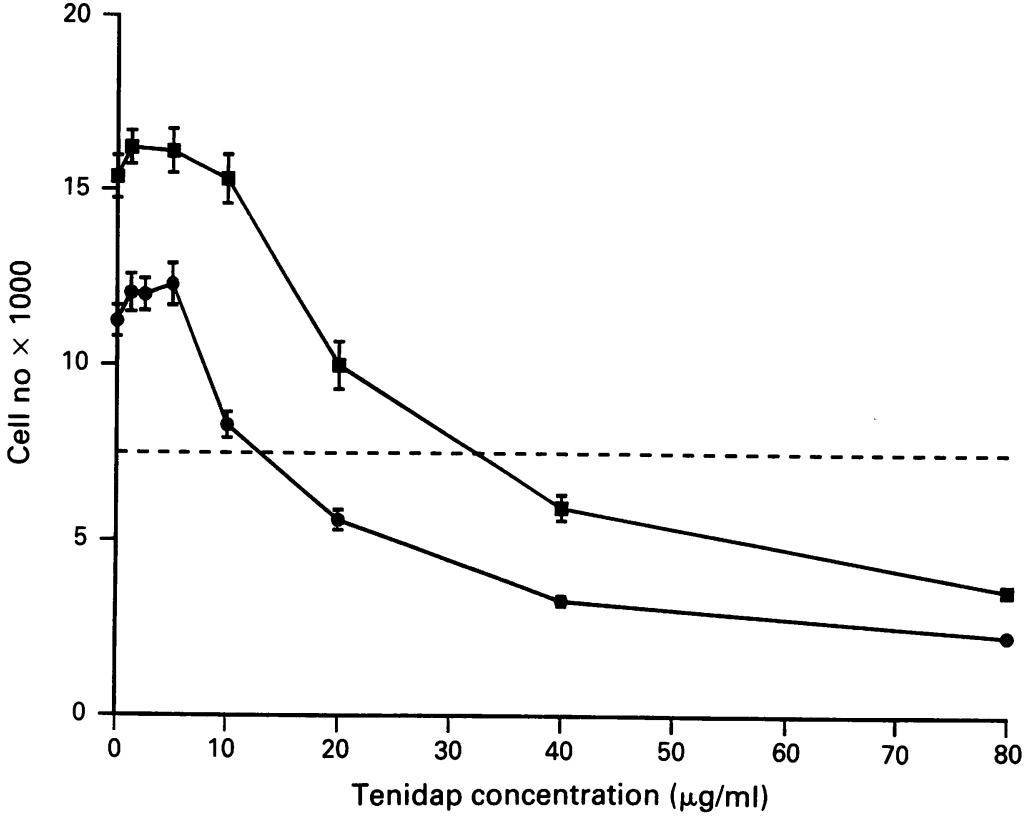

Figure 1 Typical seven day growth responses of synovial fibroblasts in SFM ( $\bullet$ ) and $C C M(\square)$ in the presence of different concentrations of Tenidap. An increase in growth is seen over the concentration range 1.25-5 $\mu \mathrm{g} / \mathrm{ml}$ with a sharp decrease in growth at 10 $\mu \mathrm{g} / \mathrm{ml}$ in SFM and $20 \mathrm{ug} / \mathrm{ml}$ in CCM. Each point represents the mean(SEM) of nine experiments carried out in quadruplicate. Dotted line represents cell numbers at day 0.

Table 1 Effect of Tenidap (5 $\mu \mathrm{g} / \mathrm{ml})$ on the seven day growth of synovial fibroblasts in the presence of different cytokines

\begin{tabular}{lrlll}
\hline Treatment & \multirow{2}{*}{$N$} & \multicolumn{2}{c}{ Mean \% growth (SEM) } & \multirow{2}{*}{$p$ value } \\
\cline { 2 - 4 } & & without Tenidap & with Tenidap & \\
\hline SFM & 28 & 100 & $134(8 \cdot 6)$ & $<0 \cdot 002^{\star}$ \\
IL-1 $(1 \mathrm{ng} / \mathrm{ml})$ & 37 & $215(22)$ & $304(32)$ & $<0 \cdot 0001^{\star \star}$ \\
TNF $(5 \mathrm{ng} / \mathrm{ml})$ & 21 & $190(21)$ & $258(33)$ & $<0 \cdot 0001^{\star \star}$ \\
IL-6 $(5 \mathrm{ng} / \mathrm{ml})$ & 8 & $99(8 \cdot 8)$ & $151(13)$ & $<0 \cdot 02^{\star}$ \\
bFGF $(10 \mathrm{ng} / \mathrm{ml})$ & 11 & $137(10)$ & $186(13)$ & $<0 \cdot 02^{\star}$ \\
TGFB $(5 \mathrm{ng} / \mathrm{ml})$ & 5 & $137(17)$ & $156(31)$ & $>0 \cdot 1+$ \\
\hline
\end{tabular}

$\mathrm{N}$ = number of experiments.

${ }^{\star} \mathrm{p}$ value obtained from Wilcoxon Test for matched pairs.

$\star \star \mathrm{p}$ value obtained from paired $t$ test.

+ not significant

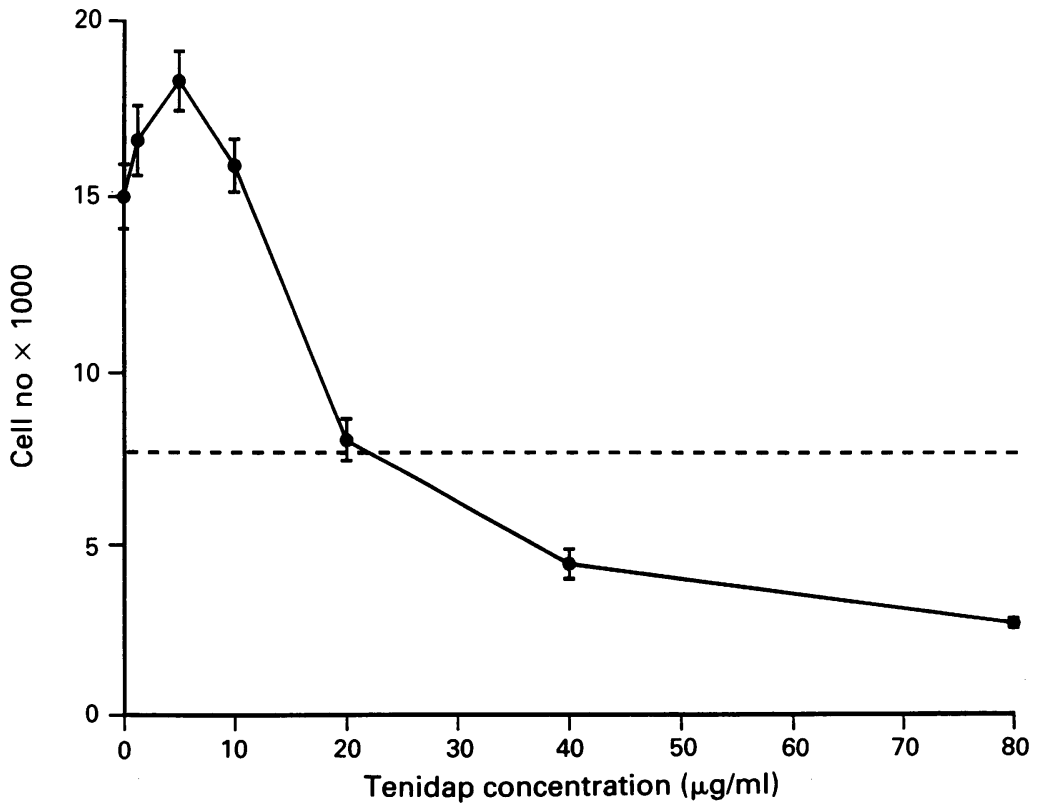

Figure 2 Typical seven day growth response of synovial fibroblasts in SFM + IL-1 (1 ng) $\mathrm{ml}$ ) and different concentrations of Tenidap. Growth is significantly increased in $5 \mu \mathrm{g} / \mathrm{ml}$ Tenidap but is sharply reduced at $20 \mu \mathrm{g} / \mathrm{ml}$ and above. Each point represents the mean(SEM) of six experiments carried out in quadruplicate. Dotted line represents cell numbers at day 0. caused gradual detachment of cells over the seven day period of the assay. Trypan blue staining revealed that many cells were no longer viable. In SFM, adherent cell numbers were reduced by $50 \%$ over seven days in the presence of $20-25 \mu \mathrm{g} / \mathrm{ml}$ Tenidap (fig 1), and more than $80 \%$ of detached cells were dead on day 7 (not shown). In CCM an equivalent result was achieved by $45-55 \mu \mathrm{g} / \mathrm{ml}$ (fig 1 ). Cells cultured in SFM containing $0.5 \%$ instead of $0 \cdot 1 \%$ BSA were more resistant to Tenidap toxicity with a $50 \%$ reduction in numbers occurring at approximately $80 \mu \mathrm{g} / \mathrm{ml}$ (not shown).

In SFM, a significant increase $(p<0.002)$ in proliferation of synovial fibroblasts was noted in response to Tenidap at $1 \cdot 25-5 \mu \mathrm{g} / \mathrm{ml}$ (fig 1 , table 1). The ability of Tenidap to stimulate cell proliferation did not appear to be related to type of disease or cell passage number although there were variations in the growth response. More than half the cell cultures examined (9/17) showed a significant increase in growth. Similar results were obtained with cells cultured in CCM.

\section{(2) Tenidap + IL-1 alpha}

All cell cultures but one (16/17) demonstrated significantly increased growth in response to IL-1 alpha $(1 \mathrm{ng} / \mathrm{ml})$ in SFM or CCM (table 1). In the presence of IL-1 alpha + Tenidap (5 $\mu \mathrm{g} / \mathrm{ml}$ ) there were further marked increases in growth (table 1). This included cell cultures that showed little or no growth response to Tenidap alone. The one cell culture that failed to respond to IL-1 alpha alone also showed no increased growth upon addition of Tenidap. The proliferative response to IL-1 + Tenidap was found in synovial fibroblasts from patients with a number of rheumatic diseases including $\mathrm{RA}, \mathrm{OA}, \mathrm{AS}$ and pigmented villonodular synovitis. A significant increase was also seen in the proliferation of normal skin fibroblasts and those from a patient with scleroderma (data not shown). Maximum growth was obtained in the presence of $5 \mu \mathrm{g} / \mathrm{ml}$ Tenidap (fig 2). Similar results were obtained with cells cultured in IL-1 + CCM although the maximum growth response occurred at 10 $\mu \mathrm{g} / \mathrm{ml}$ in some cases (not shown).

\section{(3) Indomethacin + IL-1 alpha}

Indomethacin was similar to Tenidap in causing an increase in cell proliferation which was enhanced in the presence of IL-1 (fig 3). The maximal IL-1 + indomethacin induced stimulation was usually less than the maximal increase seen in the presence of IL$1+$ Tenidap. The addition of indomethacin $(1 \cdot 0 \mu \mathrm{g} / \mathrm{ml})$ to IL-1 alpha + Tenidap $(5 \mu \mathrm{g} / \mathrm{ml})$ caused no further stimulation of cell growth. At higher concentrations $(5.0 \mu \mathrm{g} / \mathrm{ml}$ and above) indomethacin reduced the proliferative response to IL-1 + Tenidap.

\section{(4) Addition of $P G E_{2}$}

Tenidap may augment IL-1 alpha induced proliferation by blocking eicosanoid synthesis, 


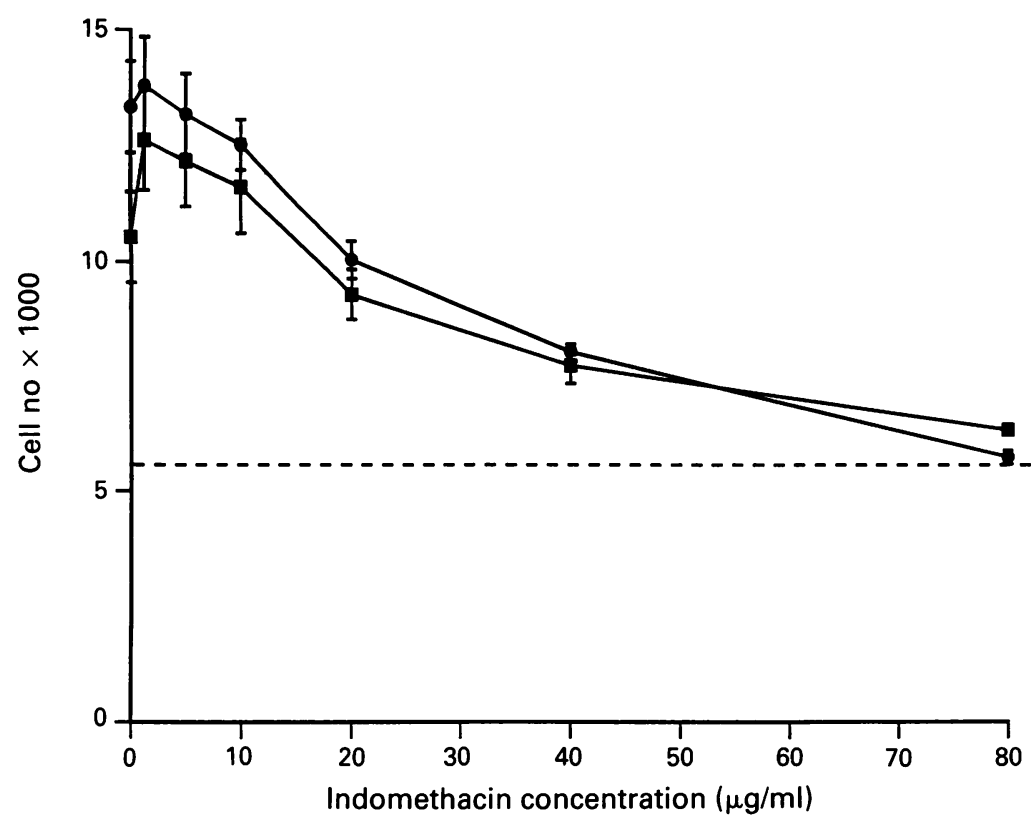

Figure 3 Effect of indomethacin on the seven day growth of synovial fibroblasts in SFM with (@) or without (0) IL-1 (1 ng/ml). A small increase in IL-1 induced proliferation was seen at $1 \mu \mathrm{g} / \mathrm{ml}$ indomethacin. Each point represents the mean(SEM) of six experiments carried out in quadruplicate. Dotted line represents cell numbers at day 0.

thus preventing the production of growth inhibitory prostaglandins which act as a negative feedback mechanism on IL-1 induced stimulation. Since $\mathrm{PGE}_{2}$ is normally produced by synovial fibroblasts in response to IL-1 and is reported to have growth inhibitory properties, we added this prostaglandin at various concentrations $(3-100 \mathrm{ng} / \mathrm{ml})$ to cell cultures with IL-1 alpha $(1 \mathrm{ng} / \mathrm{ml})+$ Tenidap (5 $\mu \mathrm{g} / \mathrm{ml}$ ). $\mathrm{PGE}_{2}$ at $3 \mathrm{ng} / \mathrm{ml}$ showed no inhibitory effect on growth. At higher concentrations of $\mathrm{PGE}_{2}$, the growth augmented by Tenidap was reduced. However, even at $100 \mathrm{ng} / \mathrm{ml}$ the growth response was still higher than in SFM + IL-1 alpha alone (fig 4).

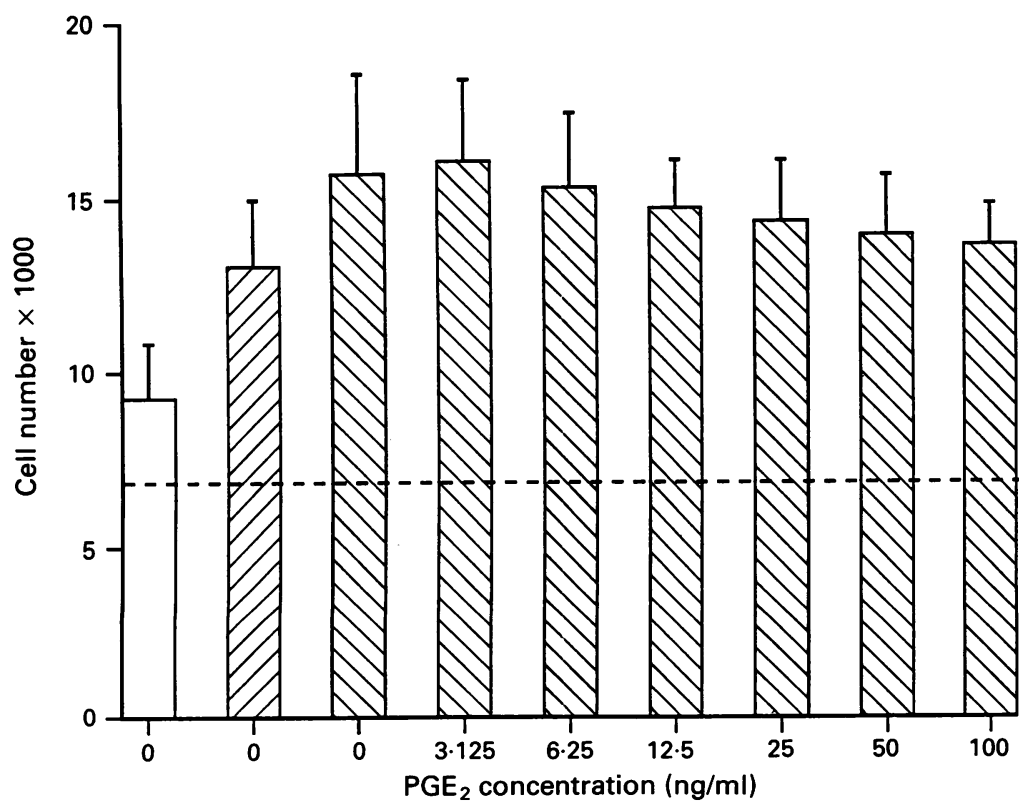

Figure 4 Growth response of synovial fibroblasts in Tenidap $I L-1$ and different concentrations of PGE2. Cells were cultured for seven days in SFM ( $\square$, SFM + Tenidap $(5 \mu \mathrm{g} / \mathrm{ml})(\mathbb{Z}), S F M+$ Tenidap $+I L-1$ (\$) with different concentrations of PGE2. Data are representative of experiments carried out on three different cell cultures in quadruplicate. Error bars represent the SEM. Dotted line represents cell numbers at day 0.
This suggests that other factors apart from $\mathrm{PGE}_{2}$ are important in limiting IL-1 alpha induced growth.

\section{(5) Tenidap + other cytokines}

TNF alpha (5 ng/ml) in SFM induced significant growth increases (table 1). Growth was increased further by addition of Tenidap. Il-6 (5 ng/ml) caused little or no change in cell proliferation (compared with SFM alone) in the cell lines tested (table 1). Addition of 5 $\mu \mathrm{g} / \mathrm{ml}$ Tenidap to IL-6 containing cultures increased cell growth to levels equivalent to those seen in Tenidap alone. Basic FGF (10 $\mathrm{ng} / \mathrm{ml}$ ) in SFM stimulated small but significant increases in synovial fibroblast proliferation and further increases were seen upon addition of Tenidap (table 1). The growth increases seen in the presence of TGF $\beta$ or TGF $\beta$ + Tenidap were not statistically significant.

PGE $_{2}$ PRODUCTION

The amounts of $\mathrm{PGE}_{2}$ in culture media after seven days of treatment with cytokines in the presence or absence of Tenidap $(5 \mu \mathrm{g} / \mathrm{ml})$ are shown in table 2. Maximum $\mathrm{PGE}_{2}$ production occurred in media containing IL-1 $(1 \mathrm{ng} / \mathrm{ml})$. High levels were also found in TNF treated cultures but little $\mathrm{PGE}_{2}$ was detected in cells cultured with IL-6 or SFM alone. Little or no $\mathrm{PGE}_{2}$ was detectable in cultures containing Tenidap.

\section{Discussion}

We have shown that Tenidap sodium at concentrations between $1 \cdot 25-5 \mu \mathrm{g} / \mathrm{ml}$ enhanced the proliferation of synovial fibroblasts in vitro. Tenidap alone in SFM or CCM increased cell growth. Furthermore, cell proliferation induced by IL-1, TNF, or bFGF was significantly increased in the presence of Tenidap. In addition Tenidap increased synovial fibroblast proliferation in the presence of IL-6. The ability of Tenidap to stimulate cell proliferation was not related to the type of disease or cell passage number. Increases in cell growth were also obtained with skin fibroblasts from normal subjects and scleroderma patients (unpublished observations).

Tenidap induced proliferation of fibroblasts in vitro was dependent on drug concentration. Little or no effect on cell proliferation was seen at $<1.25 \mu \mathrm{g} / \mathrm{ml}$ while $>10 \mu \mathrm{g} / \mathrm{ml}$ growth was

Table 2 Effect of cytokines \pm Tenidap on $P G E_{2}$ production by synovial fibroblasts in vitro

\begin{tabular}{ll}
\hline Treatment & $P G E_{2}(\mathrm{pg} / \mathrm{ml})^{\star}$ \\
\hline SFM & $40 \cdot 98$ \\
SFM + Ten & $<0 \cdot 1$ \\
IL-1 $(1 \mathrm{ng} / \mathrm{ml})$ & $2013 \cdot 22$ \\
IL-1 + Ten & $<0 \cdot 1$ \\
TNF $(5 \mathrm{ng} / \mathrm{ml})$ & $1316 \cdot 43$ \\
TNF + Ten & $1 \cdot 04$ \\
IL-6 $(5 \mathrm{ng} / \mathrm{ml})$ & $32 \cdot 32$ \\
IL-6 + Ten & $<0 \cdot 1$ \\
\hline
\end{tabular}

* The data represent the mean values of 3 separate experiments on 3 cell cultures.

All experiments carried out in SFM. 
inhibited. At higher concentrations $(>15 \mu \mathrm{g})$ $\mathrm{ml}$ ) Tenidap was toxic to cells in SFM although the toxicity was significantly reduced by incubating cells in SFM containing higher levels of BSA, or in medium with $10 \%$ FCS. This may be explained by increased binding of Tenidap to protein under these conditions. More than $99 \%$ of Tenidap is reversibly bound to human plasma proteins over the range of 1-100 $\mu \mathrm{g} / \mathrm{ml}$. (Pfizer Central Research).

It has been shown previously that indomethacin enhances IL-1 and TNF induced proliferation of synovial fibroblasts in the presence of serum, ${ }^{11}$ probably through inhibition of $\mathrm{PGE}_{2}$ production. We have confirmed this using a range of indomethacin concentrations in SFM. However, the maximal growth stimulation produced in the presence of IL-1 + indomethacin was less than the maximal stimulation by IL-1 + Tenidap. Furthermore, high levels of $\mathrm{PGE}_{2}(100 \mathrm{ng} / \mathrm{ml})$ only caused partial inhibition of the cell growth induced by Tenidap + IL-1. Exogenous $\mathrm{PGE}_{2}$ added at concentrations equivalent to those found in IL-1 treated cultures $(2-3 \mathrm{ng} / \mathrm{ml}$ ) had little or no effect on the growth of cells in Tenidap + IL-1. Recent work by Taylor et $a l^{6}$ has questioned the concept that PGE is an important growth inhibitor in synovial fibroblasts since cytokine combinations which stimulated high levels of PGE production also caused increased proliferation. Our results suggest that augmentation of synovial fibroblast proliferation by Tenidap cannot be explained by inhibition of $\mathrm{PGE}_{2}$ production alone. This suggestion is reinforced by the demonstration that Tenidap is able to augment synovial fibroblast proliferation in SFM alone or in the presence of cytokines such as bFGF and IL-6 which do not stimulate $\mathrm{PGE}_{2}$ production..$^{20}$ In contrast to our results with Tenidap, a previous study showed that indomethacin had no potentiating effect on bFGF induced synovial proliferation. ${ }^{20}$

There have been conflicting reports on the effects of IL-1 on fibroblast proliferation with some studies showing little or no stimulatory effects $^{13622}$ while others have shown significant stimulation. ${ }^{11}{ }^{12}$ However, a number of these studies have used different fibroblast types such as human lung fibroblasts ${ }^{22}$ or human foreskin fibroblasts, ${ }^{12}$ and often only one cell line was examined. We agree with Remmers $e t a l^{3}$ that conflicting results from different studies may be due to differences in cell type, cell passage number and the type of growth assay used. Clearly, caution is called for in the interpretation of these studies and their relationship to fibroblast proliferation in the synovial joint.

To try and overcome some of these difficulties we examined a large number of cell cultures $(n=17)$ from patients with a variety of rheumatic conditions, and growth was investigated over a range of passage numbers. There were certainly variations in the total amount of growth between cell cultures and between passage numbers (data not shown), although overall there was a clear demonstration of enhanced growth in the presence of
Tenidap. In our experience the variations in growth between cell cultures were not related to the type of disease or severity of disease in the patients from which they were obtained. Moreover, although most cell cultures exhibited slower growth with increasing passage number, some cell cultures still showed significant proliferation at passage numbers $>25$. Even in slower growing cells at high passage numbers $(>20)$ Tenidap caused significant augmentation of cytokine induced growth.

We found in both serum free and serum containing media that Tenidap stimulated cell proliferation with and without cytokines. It should be pointed out that our serum free medium contained some protein $(0 \cdot 1 \%$ BSA $)$ as well as transferrin, selenium and the progression factor, insulin, which may act synergistically with other growth factors. ${ }^{23}$ Indeed, we have found that insulin synergises with IL-1 to increase growth of synovial fibroblasts (unpublished observations). In contrast to many previous studies we used an assay that reflects the actual change in cell numbers. Although $\left[{ }^{3} \mathrm{H}\right]$ thymidine incorporation is widely considered to correlate with cell growth, this type of assay can produce misleading results since increased thymidine uptake does not always correlate well with increases in cell number. ${ }^{324}{ }^{25}$ Also, the full effect of a particular cytokine on cell growth may be underestimated by $\left[{ }^{3} \mathrm{H}\right]$ thymidine incorporation which is usually carried out over a relatively short time period (24-48 hours). Release of other growth factors from the cytokine treated cells may occur at some time after initial stimulation so that the eventual increase in fibroblast numbers results from an indirect autocrine mechanism. ${ }^{26}$ In our study synovial fibroblasts continued to proliferate over the seven day culture period. Although changes in cell number were measurable after two to three days, differences between treatments were more apparent after seven days.

The consequences of stimulating synovial fibroblast growth in vivo are still unclear. It is generally assumed that increased proliferation of these cells is associated with the progression of RA, with evidence from histomorphological studies showing a close temporal relationship between rapid proliferation of fibroblast-like cells of the synovium and articular cartilage destruction. ${ }^{27}$ However, while it is clear that synovial fibroblasts have the potential to produce many pro-inflammatory agents they may also be involved in anti-inflammatory processes, including tissue repair. For example, IL-1 will promote synthesis and release of both collagenase and its inhibitor (tissue inhibitor of metalloproteinase, TIMP), as well as ECM components such as collagen and fibronectin. ${ }^{28}$ Thus increased proliferation of synovial fibroblasts in vivo may not be damaging per se, rather it is alterations in their state of activation and changes in the balance between production of pro- and anti-inflammatory mediators which are important.

In vitro studies have indicated that Tenidap inhibits the production of IL-1 and TNF in 
human peripheral blood mononuclear cells by $70-80 \%$ at concentrations slightly lower than those clinically achievable $(20 \mu \mathrm{g} / \mathrm{ml}) .^{29}$ It also inhibits the activity of IL- 1 in T cell activation ${ }^{17}$ and down regulates IL-1 receptor expression in human chondrocytes. ${ }^{30}$ The results from our study indicate that Tenidap at low concentrations (up to $10 \mu \mathrm{g} / \mathrm{ml}$ ) does not inhibit the mitogenic activity of IL-1 alpha, TNF alpha or bFGF on human synovial fibroblasts, although at possible therapeutic levels $(15-20 \mu \mathrm{g} / \mathrm{ml})$ it does inhibit growth even in the presence of cytokines. Our data suggest that the concentration of Tenidap achieved in vivo in the local environment of the joint, and the availability of bioactive cytokines may be critical factors in the effect of this agent on synovial fibroblast proliferation.

Research was funded by the Haywood Rheumatism Research and Development Foundation, and Pfizer Ltd. We would like to thank Pfizer for providing the Tenidap.

1 Kumkumian G K, Lafyatis R, Remmers E F, Case J P, Kim $S \mathrm{~J}$, Wilder R L. Platelet derived growth factor and IL-1 interactions in rheumatoid arthritis. F Immunol 1989; 143. 833-7.

2 Brinkerhoff C E. Morphologic and mitogenic responses of rabbit synovial fibroblasts to transforming growth factor $\beta$ require transforming growth factor-alpha or epidermal $\beta$ require transforming growth factor-alpha or

3 Remmers E F, Lafyatis R, Kumkumian G K, et al. Cytokines and growth regulation of synoviocytes from patients with rheumatoid arthritis and rats with streptococcal cell wall arthritis. Growth factors 1990; 2: 179-88.

4 Hamerman D, Taylor S, Kirschenbaum I, et al. Growth factors with heparin binding affinity in human synovial fluid. Proc Soc Exp Biol and Med 1987; 186: 384-9.

5 Thornton S C, Por S B, Penny R, Richter M, Shelley L, Breit S N. Identification of the major fibroblast growth factors released spontaneously in inflammatory arthritis as factors released spontaneously in inflammatory arthritis as platelet derived growth factor and tumour

6 Taylor D J, Feldmann M, Evanson J M, Woolley D E. Comparative and combined effects of transforming factor-alpha and $\beta$ interleukin-1 and interferon- $Y$ on rheumatoid synovial cell proliferation, glycolysis and prostaglandin E production. Rheumatol Int 1989; 9: 65-70.

7 Bucala R, Ritchlin C, Winchester R, Cerami A. Constitutive production of inflammatory and mitogenic cytokines by production of inflammatory and mitogenic cytokines by 569-74.

8 Dayer J M, Beard J, Chess L, Krane S M. Participation of monocyte-macrophages and lymphocytes in the production of a factor that stimulates collagenase and prostaglandin release by rheumatoid synovial cells. $\mathcal{f}$ Clin Invest 1979; 64: 1386

9 Case J P, Lafyatis R, Reimmers E F, Kumkumian G K, Wilder $\mathbf{R}$ L. Transin/stromelysin expression in rheumatoid synovium. Amer $f$ Pathol 1989; 135; $1055-64$.

10 Agro A, Jordana M, Chan K-H, et al. Synoviocyte derived granulocyte macrophage colony stimulating factor granulocyte macrophage colony stimulating factor mediates the surviva
11 Gitter B D, Labus J M, Lees S L, Scheetz M E. Characteristics of human synovial fibroblast activation by IL-1 $\beta$ and TNF. Immunol 1989; 66: 196-200.

12 Matsubara $T$, Hirohata K Suppression of human fibroblast proliferation by D-Penicillamine and copper sulfate in vitro. Arthr Rheum 1988; 31: 964-72.

13 Moilanen E, Alanko J, Asmawi M Z, Vapaatalo H. CP 66,248 a new anti-inflammatory agent is a new poten inhibitor of leukotriene $\mathrm{B}_{4}$ and prostanoid synthesis in human polymorphonuclear leucocytes in vitro. Eicosanoids 1988; 1: 35-39.

14 Blackburn W D, Heck L W, Loose L D, Eskra J D, Carty $\mathrm{T} \mathrm{J}$. Inhibition of 5-lipoxygenase product formation and polymorphonuclear cell degranulation by Tenidap sodium in patients with rheumatoid arthritis. Arth Rheum 1991; 34: 204-210.

15 Otterness I G, Bliven M L, Downs J T, Natoli E J, Hanson D C. Inhibition of interleukin 1 synthesis by tenidap: new drug for arthritis. Cytokine 1991; 3: 277-83.

16 Sipe J D, Bartle L M, Loose L D. Modification of proinflammatory cytokine production by the antirheumatic agents Tenidap and Naproxen. $f$ Immunol 1992; 148 480-4.

17 McDonald B, Lowe L, Rosenwasser L J. The influence of a novel arachidonate inhibitor, CP- 66,248 on the production and activity of human monocyte IL-1. Arth Rheum 1988; 31(Suppl 4: S17, Abst).

18 Blackburn W D, Loose I D, Heck L W, Chatham W W Tenidap, in contrast to several available non steroidal anti-inflammatory drugs, potently inhibits the release of anti-inflammatory drugs, potently inhibits the release of
activated neutrophil collagenase. Arth Rheum 1991; 34: activated

19 Kueng W, Silber E, Eppenberger U. Quantification of cell cultured on 96 well plates. Anal Biochem 1989; 182 16-19.

20 Butler D M, Leizer T, Hamilton J A. Stimulation of human synovial fibroblast DNA synthesis by platelet derived growth factor and fibroblast growth factor. 7 Immunol 1989; 142: 3098-103.

21 Guerne P-A, Zuraw B L, Vaughan J H, Carson D A, Lotz M. Synovium as a source of interleukin 6 in vitro: contribution to local and systemic manifestations of contribution to local and systemic mat
arthritis. $\mathcal{F}$ Clin Invest $1989 ; 83$ : 585-92.

22 Thornton S C, Por S B, Walsh B J, Penny R, Breit S N Interaction of immune and connective tissue cells. 1 . The effect of lymphokines and monokines on fibroblast growth. F Leuk Biol 1990; 47: 312-20.

23 Rosengurt E. Signal transduction pathways in mitogenesis. In: Waterfield MD, ed. Growth factors. London: Churchill Livingstone, 1989: 513-28.

24 Elias L. Stimulation by tumor necrosis factor of HL-60 thymidine salvage pathway metabolism dissociated from thymidine salvage pathway metabolism dissocit

25 Ho C-K, Ou B-R, Hsu M-L, Su S N, Yung C-H, Wang S-Y Induction of thymidine kinase activity and clonal growth of certain leukemic cell lines by a granulocytic-derived factor. Blood 1990; 75: 2438-44.

26 Raines E W, Dower S K, Ross R. Interleukin-1 mitogenic activity for fibroblasts and smooth muscle cells is due to PDGF-AA. Science 1984; 243: 393-6.

27 Fassbender H G. Histomorphological basis of articular cartilage destruction in rheumatoid arthritis. Collagen Relat Res 1983; 3: 141-55.

28 Krane S M, Dayer J M, Simon L S, Byrne M S. Mononuclear cell conditioned medium containing
mononuclear cell factor (MCF) homologous with interleukin 1 stimulates collagen and fibronectin synthesis interleukin 1 stimulates collagen and fibronectin synthesis
by adherent rheumatoid synovial cells. Effects of by adherent rheumatoid synovial cells. Effects of prostaglandin $\mathrm{E}_{2}$

29 Schlegel S I. General characteristics of non steroidal antiinflammatory drugs. In: Paulus $\mathrm{H}$ E, Furst $\mathrm{D}$ E Dromgoole S, eds. Drugs for rheumatic disease. New York: Churchill Livingstone, 1987: 203.

30 Pelletier J P, McCollom R, Martel-Pelletier J. Regulation of human chondrocyte IL-1 receptor expression by cytokines and anti-rheumatic drugs. Arth Rheum 1990; 33(Suppl 9: 22, Abst). 